東北家畜臨床研究会会報。 $\quad$ No $8,25 \sim 30$

\title{
黒毛和種の汎腎炎を伴った結節性動脈周囲炎の 一症例について
}

福島県農業共済組合連合会

浜家畜診療所

坂本公一・内田幸四郎・豊田洋一

は じ め に

結節性動脈周囲炎（Periarteritis nodosa，以下P \& MAIERによってはじめて報告された疾患で，病理発生としては自己免疫性疾患が考えられているが， 原因は不明とされている5 。

本症は, 彭断基準が病理組織学的レベルの系統的血管疾患であり，この病理組織学的所見が同時に臨 床診断をもかねているとてろに特徴がある゙う。

家畜における P Nの発生は比較的まれとされ，また本症の特殊性のためか日本における発生例につい ての報告はきわめて少ない4)。

今回著者らは, 臨床的に重度の尿毒症状を呈し，末期には昏睡となった黒毛和種の一例に遭遇し，病 理組織検查を実施した結果，汎腎炎を伴った P Nと款断された。よってての症例について概要を報告す る。

\section{症 例牛亡検 查 結 果}

1. 発生状況

昭和 60 年 1 月，当管内のU農家に発生した。当農家では，繁殖用黒毛和種の成牛 6 頭，育成牛 2 頭 の計 8 頭が飼養されていた。

症例牛は生後 8 か月の育成牛の雌で，育成牛の発育は良好，既往症はなかった。また，当農家の飼 養環境などは良好であった。

\section{2. 臨床症状 (表一1)}

患牛の体温は初診時上昇したが，第 3 病日より低体温で推移し，終始沈うつ状態で元気，食欲は减 退していた。第 3 病日より歩様蹌䠗から起立不能に陥り，第 5 病日に至り泥状血便を排泄したが，末 期には硬固便となった。

眼結膜および胵粘膜は，初期重度のチアノーゼを呈したが，末期には黄㾝色を呈した。特に腟粘膜 では第 3 〜第 5 病日に点状出血が認められた。第 7 病日より両眼球ガラス体内に膜状の浮遊物が認め られた。

3. 血液検查所見 (表一2)

第 3 病日では, W B Cの増加と $\mathrm{H} t ， \mathrm{BUN}$ ，クレアチニン，総ビリルビン，G O T およびC P K の 高度の上昇がみられた。第 9 病日では，特に総ビリルビンの上昇が顕著であった。2 回の血液検査で 軽度の低蛋白血症と高度の低 $\mathrm{Ca}$ 高 $\mathrm{P}$ 血症が認められた。 
白血球百分比については，特に異常が認められなかった。

表一 1 . 臨 床 症 状

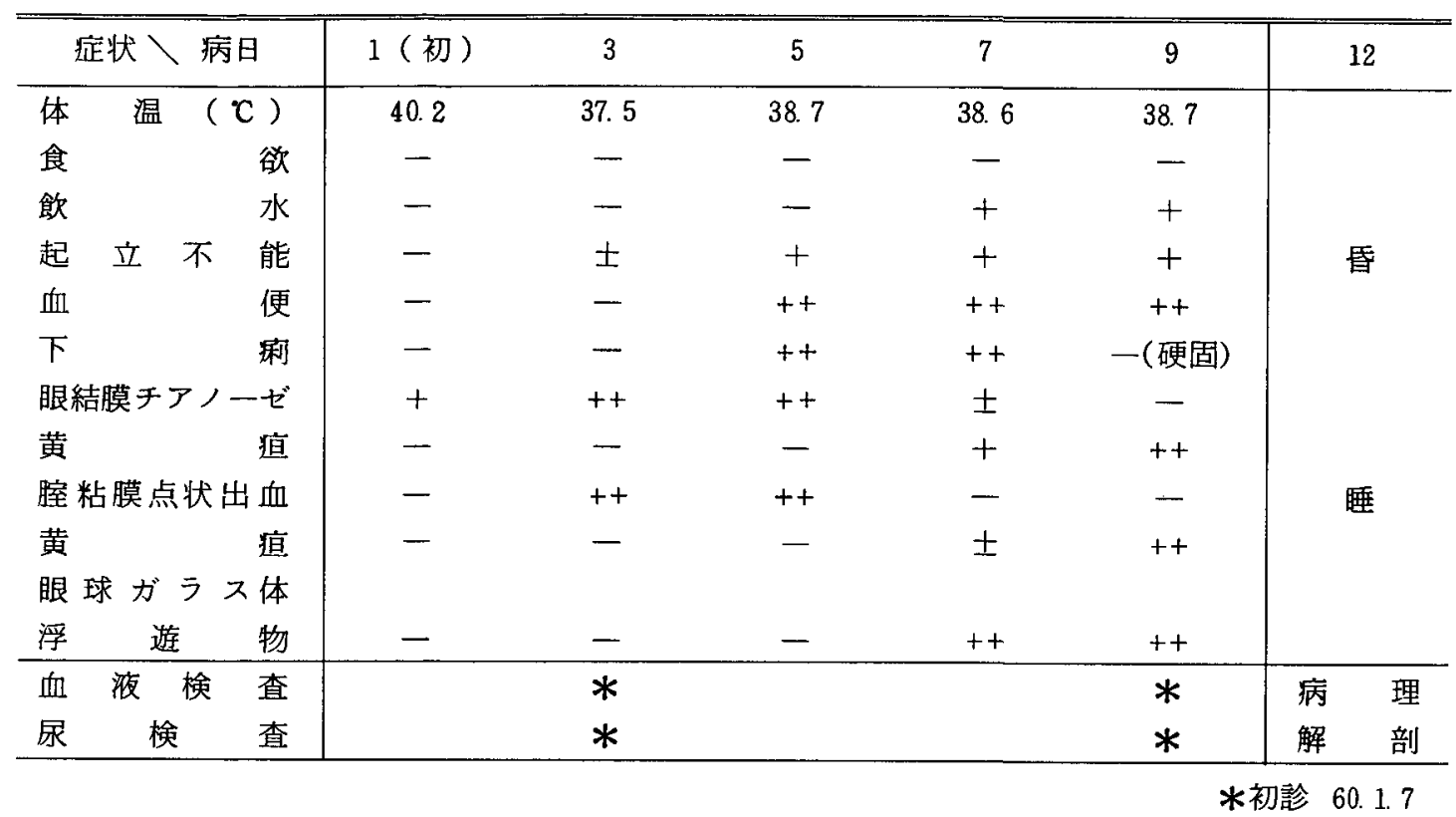

表一 2 . 血液検査所晃

\begin{tabular}{|c|c|c|}
\hline 項 目】病 日 & 3 & 9 \\
\hline W B C & 11,300 & 11,600 \\
\hline$(\%)$ & 53 & 38 \\
\hline$s-\mathrm{TP} \quad(g / d \ell)$ & 5. 3 & 5. 0 \\
\hline$(g / d l)$ & 2. 61 & 2. 39 \\
\hline $\int a$ & 1. 62 & 1. 38 \\
\hline G lob & 0.51 & 0.60 \\
\hline$(g / d l)$ & 0.53 & 0.63 \\
\hline $\mathrm{A} / \mathrm{G}$ & 0. 97 & 0. 91 \\
\hline $\mathrm{BUN} \quad(m g / d \ell)$ & 84. 1 & 112. 5 \\
\hline クレアチニン $(m g / d \ell)$ & 7. 9 & 8. 5 \\
\hline 総ビリルビン $(m g / d \ell)$ & 3. 6 & $7<$ \\
\hline $\operatorname{GOT}(\mathrm{KU})$ & 570 & 870 \\
\hline$(m u / m l)$ & 1,225 & 1,313 \\
\hline$(m g / d \ell)$ & 5. 8 & 6. 1 \\
\hline$(m g / d l)$ & 14. 4 & 15. 7 \\
\hline ユニ グラフ $(m g / d \ell)$ & $80<$ & $80<$ \\
\hline
\end{tabular}

4. 尿検查所見 ( 表一 -3 )

2 回の検査で尿，尿の混濁，比重の低下，細胞を含む沈查，pHの低下，高度の潜血および尿蛋 白がみられた。尿沈査中に細菌像は認められなかった。 
表一 3. 尿 検 查所見

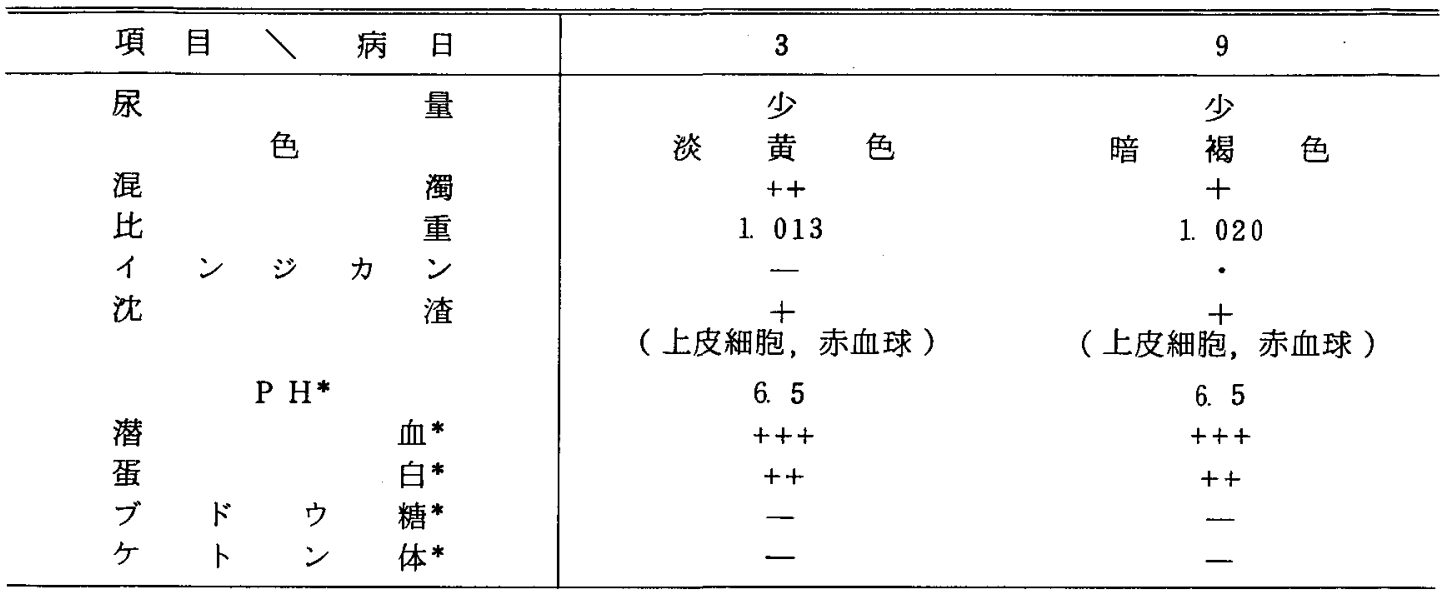

*ラブスティックス

5. 剖 検 所見

腎臟は軽度に腫大して退色していた。また割面において腎肧部に出血がみられた。

盲腸体部に直径 $5 \mathrm{~cm}$ の馬蹄形の穿孔性漬湯がみられ，小腸と感着していた（図一1）。

肝臓は軽度に腫大し，割面において黄褐色の肝小葉が明僚に認められた。また胆のうは小児頭大に 肥大し，多量の胆汁を入れていた $($ 図一2)。

その他の藏器，器官には，肉眼的に特に異常は認められなかった。

\section{6. 病理組織学的所見}

病理組織材料は10\%ホルマリン液で固定し, 型のでとくパラフィン包埋した後, ヘマトキシリンエ オジン染色，アザン染色，PAS染色，コンゴーレッド染色を実施した。

腎臓皮質では，小動脈の内膜から中膜にかけてフィブリノィド様物質の貯留（図一3）と中膜の壊 死および外膜の細胞浸潤がみられた。また，腎系球体にも軽度のフィブリノィド様物質の貯留と多形 核白血球の細胞浸潤が分節状にみられた（図一4）。

一部尿細管腔には，P A S 陽性物質の貯留と赤血球の充満がみられた（図一 5 ）。

腎病変は，腎単位から間質にわたってみられることから病理学的に汎腎炎といえるが，これら病変 部は全体のおよそ40\%に観察された。

心蔵の小血管では，血管内皮の増生と外膜の細胞浸潤がみられた（図一6）。その他，脾蔵，小腸 粘膜下織 (図一7) および肝臟の一部に壊死性の血管炎が観察された。特に盲腸潰演部の壊死した血 管内には，血栓様物質が認められた。

腎臓では，尿細管上皮細胞，血管病変部および系球体病変部に好塩基性の核内封入体がみられた (図-8)。

肝藏では，胆汁のウッ滞と肝細胞質内に胆汁色素の出現がみられた。

\section{7. ウイルス抗体検查成績}

第 3 ，第 9 病日のペア血清を用い，I B R 亿ついては中和試験，アデノ 7 型, パラインフルエンザ 3 型についてはH I テストを実施した。その結果アデノ抗体価は 40 倍から 1,280 倍と有意に上昇して おり，パラ，I B R抗体洒は，それぞれ10倍以下および1倍で変化は認められなかった。 


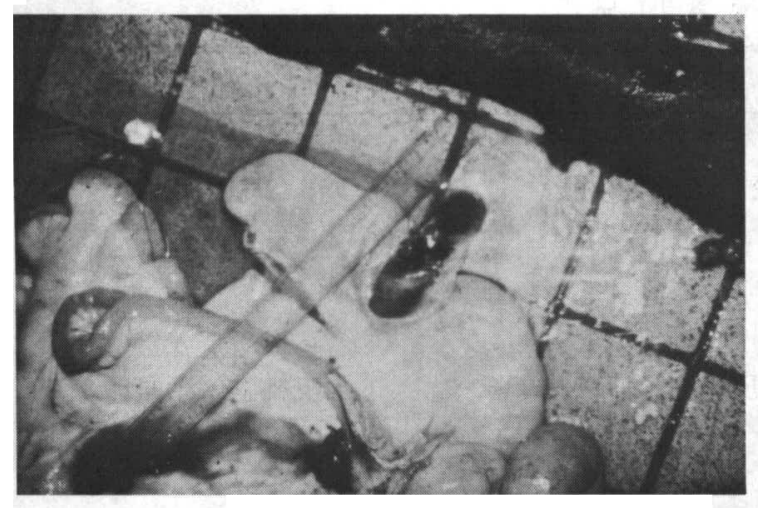

図 1. 盲腸体部の穿孔性潰瘍

図 2.肝の軽度の腫大と胆のう の著名な肥大
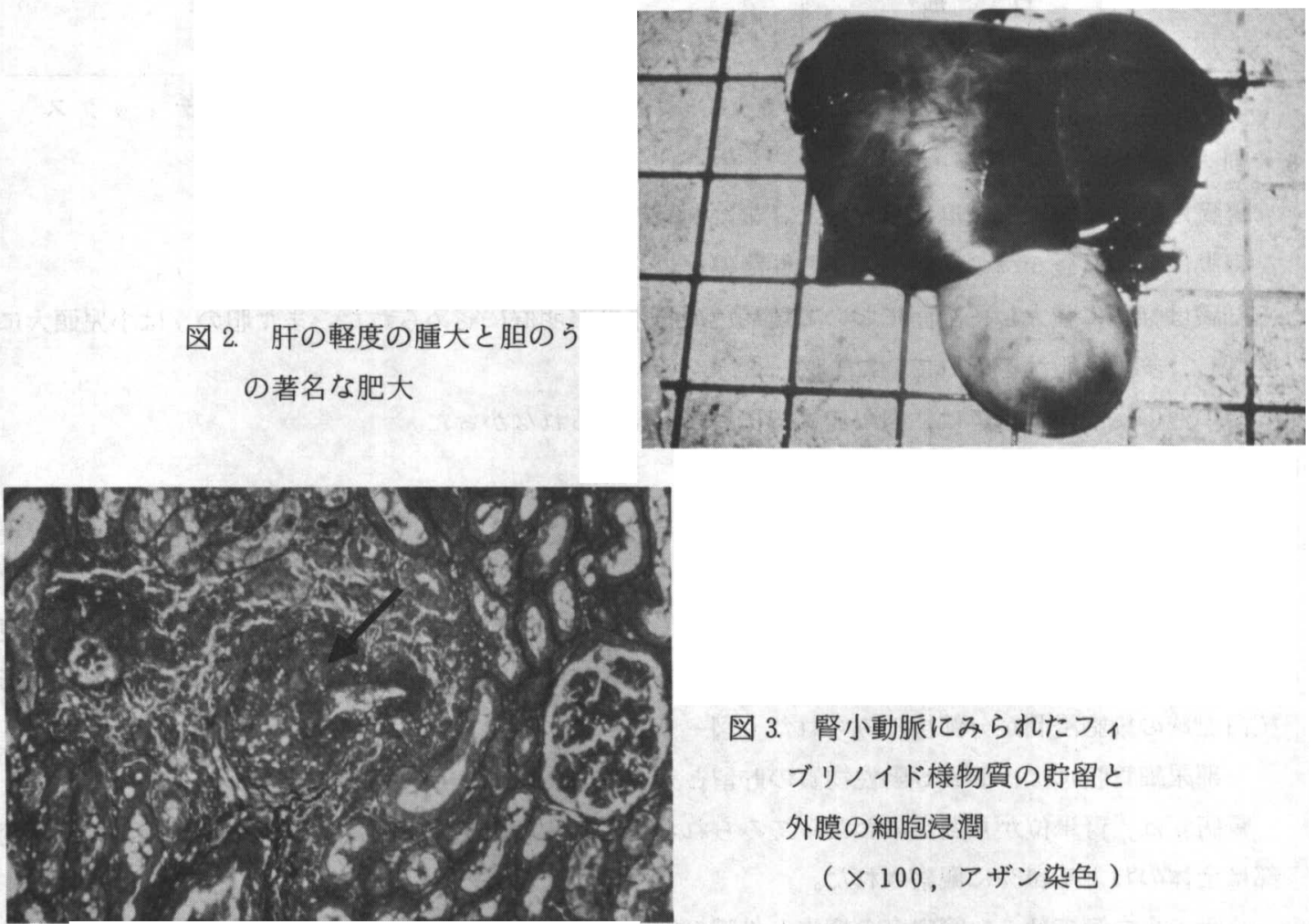

図 3.腎小動脈にみられたフィ ブリノイド様物質の貯留と 外膜の細胞浸潤 （×100，アザン染色 $)$

図 4. 腎系球体における多形核 白血球の細胞浸潤 $(\times 400$, PAS 染色 $)$

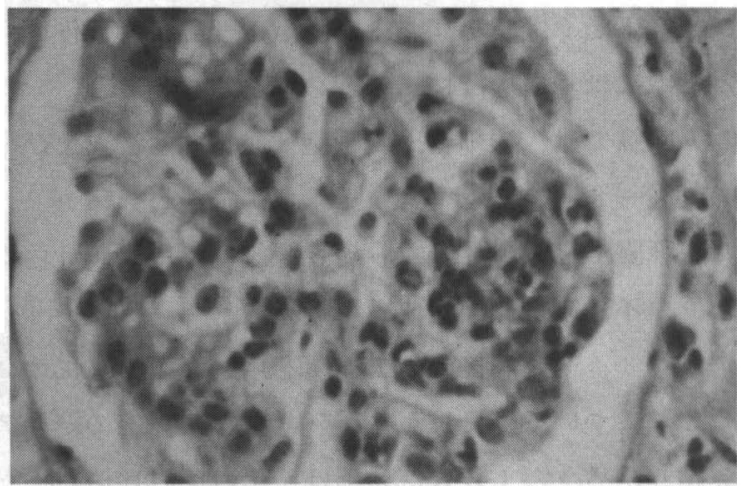




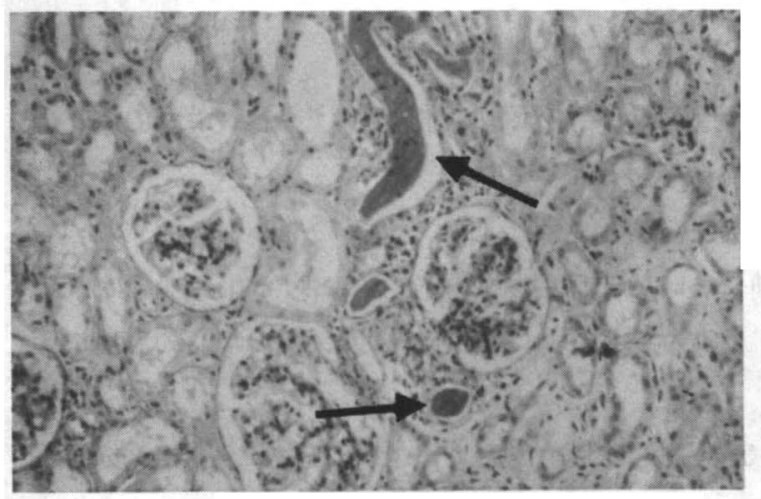

図 5. 尿細管腔にみられたPAS

陽性物質の貯留

$$
(\times 100, \text { P A S 染色 })
$$

図 6. 心藏血管内皮の増生と外 膜の細胞浸潤

$(\times 100, H E$ 染色 $)$
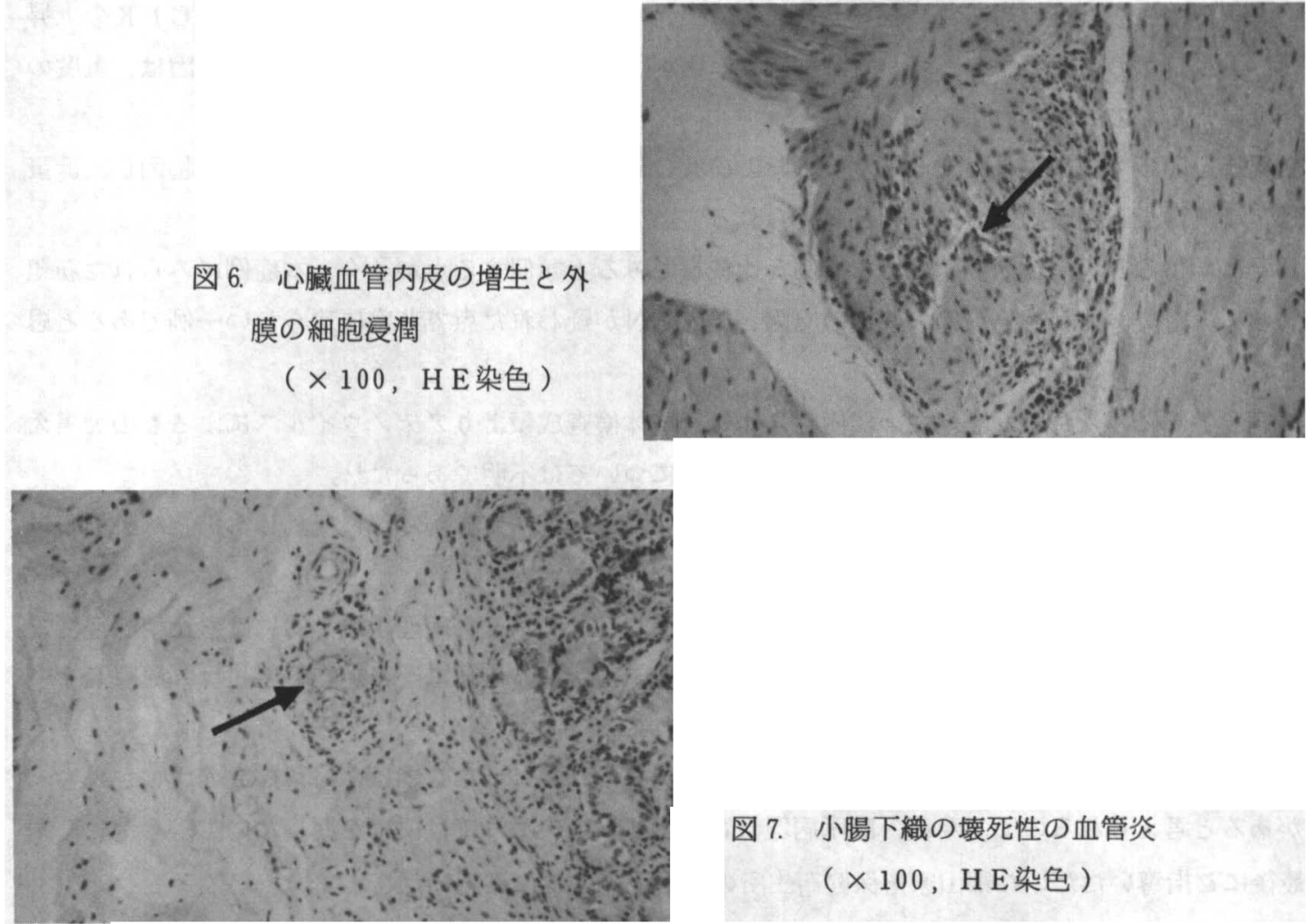

図 7. 小腸下織の壊死性の血管炎 $(\times 100, \mathrm{HE}$ 染色 $)$

図 8. 尿細管上皮細胞にみられ た好塩基性の核内封入体 $(\times 400, \mathrm{HE}$ 染色 $)$

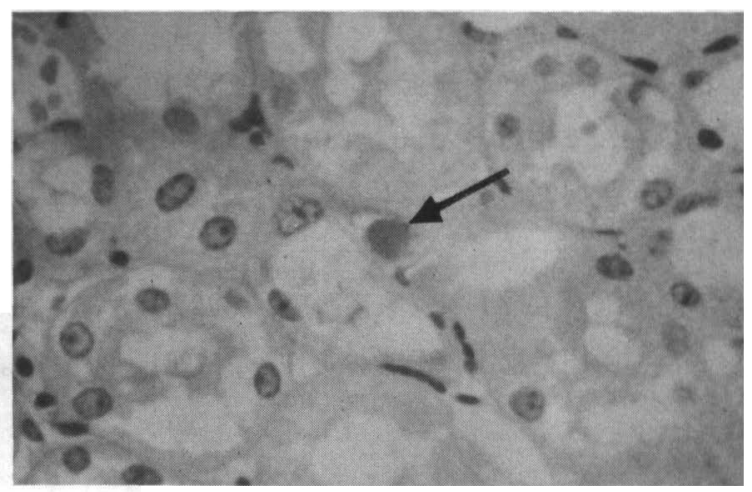


P Nは血管中膜のフィブリノイド変性が本質的な変化であり，今回の症例におけるP NはARKINの 分類にしたがえば，それぞれ炎症期から肉芽期の組織像を呈していた5)。

NUZUM らによると，ヒトにおけるPNの臓器別発生頻度は腎臟で86\%で，その他心臟，消化管，骨 格筋にも多くみられたという5)。本症例では，生前における臨床症状，尿検査における細胞を含む沈査， 混濁, 尿比重之 $\mathrm{pH}$ の低下, 蛋白尿お上び潜血尿, 血液検査における BUN, クレアチニンの高度の上 昇によって急性腎炎が疑われた。

また，起立していたにもかかわらすＣPKとGOTの高度の上昇がみられたととから，骨格筋の変性 がすでに存在していたと考えられた。

第 9 病日の血液検査でみられた総ビリルビンの上昇は, 胆汁色素のウッ滞を示し，またC P K の上昇 に比べ，GＯTの上昇が急なととから肝細胞の崩買が疑われた。末期のウッ滞性黄㡺の原因は，重度の 胃腸炎によるものと思われた。

全経過を通して認められた尿 $\mathrm{pH}$ の低下および低C a 高 P血症は，系球体濾過の減少に起因し，低蛋 白血症は沉腎炎と腸管内出血のためと考えられる゙。

ヒトにおけるP Nの臨床症状 ${ }^{5)}$ と本症例を比較してみると類似する点が多く，本症例にみられた筋組 織崩買，汎腎炎および盲腸潰㻛の共通の原因として P Nが疑われた点で非常に珍らしい一例であると思 われる。

腎病変各部にみられた好塩基性の核内封入体は，抗体検查成績よりアデノウイルスによるものと考元 られるが, アデノウイルス感染症と各病変との関連については不明であった2)。

動脈炎を伴う牛の疾病として悪性カタール熱2)も疑われたが, 血管病変部に浸潤した紐胞が小型の単 核細胞であった点から否定されだ2)。

本症例における沉腎炎，盲腸潰瑒，組織崩壊および P Nはそれぞれ病理組織学的には，比較的軽度で あったと考えられる。したがって，臨床症状からみた尿毒症より昏睡に至る病勢の悪化は，沉腎炎を中 心とするこれら病変の相互作用によるものと考えられた。

今回の症例にみられたP Nの原因についての確証が得られなかったてとは，材料採取の乏しさにも一 因があると考えられるので，今後，臨床病理検査を行なうにあたっては慎重を期したい。

最後にご指導いただいた郡山家畜保健衛生所の丹治敏夫先生に深謝いたします。

引用文献

1）白井和哉, 本好茂一監訳：臨床獣医学 I，pp，265～267，311 322, 文永堂出版, 東京。

2）稲葉右二：牛病学, $\mathrm{pp}, 281 \sim 308,348 \sim 354$, 近代出版, 東京。

3）久保, 伊沢, 戸尾監訳：家畜臨床生化学 (第三版), pp, 113 136, 229 288, 371 440, 近代出版, 東京。

4）草間正雄 $(1981)$ ，家畜診療，（222）：35～38。

5）長浜，桑原，福田：医学のありみ，126：26〜33。 